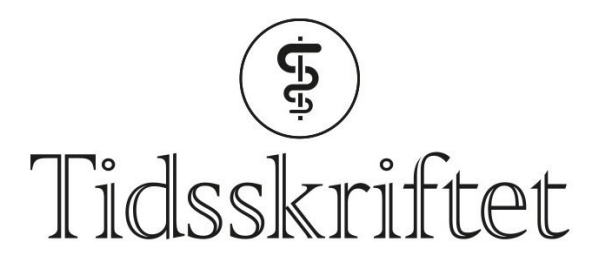

DEN NORSKE LEGEFORENING

\title{
Klinisk undervisning i koronakrisens tid
}

REDAKSJONELL KOMMENTAR

\section{PETTER GJERSVIK}

E-post: petter.gjersvik@medisin.uio.no Petter Gjersvik er professor og undervisningsleder i hud- og veneriske sykdommer og leder for en eksamenskommisjon ved profesjonsstudiet i medisin ved Universitetet i Oslo. Han er også medisinsk redaktør i Tidsskriftet.

Undervisningen av medisinstudenter fortsetter selv om auditoriene er stengt. Nå drives både teoretisk og «klinisk» undervisning digitalt med lærere og studenter foran PCskjermer på hver sin kant.

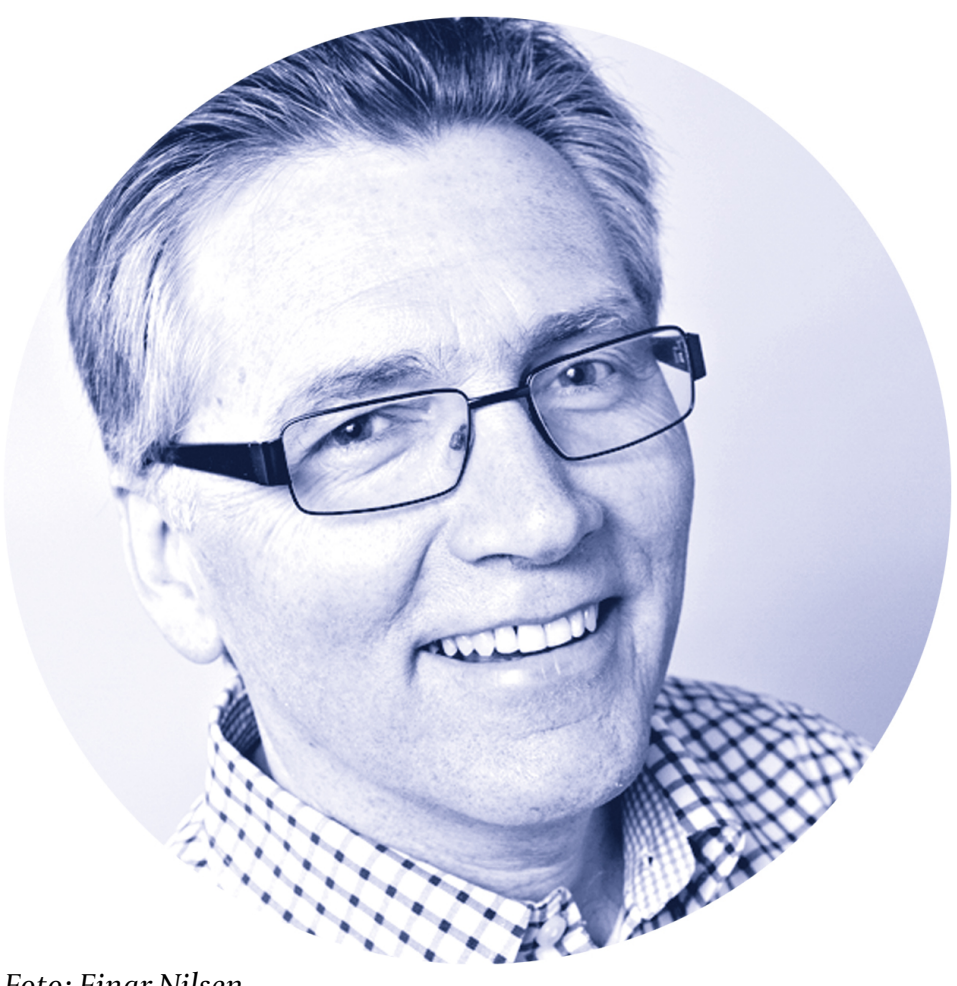

Foto: Einar Nilsen

Universitetet i Oslo ble stengt 12.3.2020 som ledd i samfunnets forsøk på å forsinke utbredelsen av koronaviruset som gir sykdommen covid-19 $(1,2)$. Alle auditorier og andre undervisningsrom på Oslo universitetssykehus er nå stengt, foreløpig for noen uker, antakelig frem til sommeren og kanskje lenger. Studentene skal holde seg hjemme. Undervisere uten klinisk rettete oppgaver og de fleste administrativt ansatte er også sendt hjem. Sykehusets kliniske funksjoner fortsetter, men med store endringer i drift og 
prioriteringer. Det samme har skjedd ved de andre fakultetene og universitetssykehusene i landet.

Stengningen av universitetene (og alle skoler og høyskoler) betyr ikke at undervisningen er lagt ned. I Oslo, for eksempel, fortsetter undervisningen av medisinstudentene tilnærmet slik timeplanen tilsier, men undervisningen skjer nå ved bruk av digitale plattformer og ikke ved oppmøte. Dette innebærer at faglærerne foreleser sittende foran en PC-skjerm, og at studentene sitter hjemme og ser, lytter og stiller spørsmål digitalt. Såkalte klinikker basert på sykehistorien og funn fra reelle pasienter, er gjort om til kasuistikkpregete forelesninger. Også smågruppeundervisningen, der studentene skulle ha hatt klinisk kontakt med mange pasienter, er lagt om. Med utgangspunkt i dels konstruerte, dels reelle (og anonymiserte) kasuistikker, presentert med tale og bilder på skjerm, kan studenter og faglærer diskutere ulike diagnostiske og terapeutiske problemstillinger. Alle personvernhensyn er ivaretatt. Ambisjonen er at studentene skal være klare til å gjennomføre og bestå planlagte eksamener før sommeren. Sannsynligvis må eksamensformene modifiseres av hensyn til smittevernet, men læringsmålene for studentene står fast. Universitetenes samfunnsansvar, å utdanne dyktige leger, skal oppfylles, også i krisetider.

Covid-19-pandemien er i ferd med å endre verden. Vil den også endre måten vi utdanner våre leger på?

Omleggingen av undervisningen gjennomføres takket være stor innsats fra studieledelse, administrativt ansatte og ikke minst alle faglærerne. Studentene viser forståelse og tålmodighet. Ved fakultetet i Oslo var mange fag, bl.a. ortopedi, kommet langt med å etablere digitale undervisningsformer allerede før omleggingen. Tilgang til digitale ressurser, som er selvsagt $i$ alle andre deler av samfunnet, gjør nå til fulle sitt inntog $i$ alle fag i legestudiet.

Covid-19-pandemien er i ferd med å endre verden. Vil den også endre måten vi utdanner våre leger på? Vil erfaringene med digital undervisning føre til mer permanente endringer i studieopplegget? Bør vi nå gjennomføre en lenge planlagt og etterlengtet digital modernisering av studiet? Eller vil vi erkjenne at god klinisk og pasientnær undervisning med tett dialog - ansikt til ansikt - mellom lærer og student er viktigere enn noensinne? Antakelig er svaret ja på alle disse spørsmålene. Covid-19-pandemien er i ferd med å endre medisinsk utdanning.

\section{LITTERATUR:}

1. Aavitsland P. Koronavirusepidemien vil ramme Norge. Tidsskr Nor Legeforen 2020; 140. doi: 10.4045/tidsskr.20.0077. [PubMed][CrossRef]

2. Fauci AS, Lane HC, Redfield RR. Covid-19 - navigating the uncharted. N Engl J Med 2020;382: NEJMe2002387. [PubMed][CrossRef]

Publisert: 26. mars 2020. Tidsskr Nor Legeforen. DOI:10.4045/tidsskr.20.0243

(C) Tidsskrift for Den norske legeforening 2020. Lastet ned fra tidsskriftet.no 